\title{
The Effectiveness of Critical Thinking Ability on Learning Outcomes at SMP Katolik Stella Maris Biudukfoho, Indonesia
}

\author{
Yohana Febriana Tabun ${ }^{1}$, Widha Sunarno ${ }^{2}$, Sukarmin ${ }^{3}$
}

\section{ARTICLE INFO}

Article History:

Received 03.04.2019

Received in revised form

17.06.2019

Accepted

Available online 01.10.2019

\begin{abstract}
This study aimed to test the influence of critical thinking ability towards the learning outcomes of the students at SMPK Stella Maris Biudukfoho. The process of collecting the sample of the experimental classroom I and the experimental classroom II was by using the cluster random sampling technique. The subject of this study numbered 60 students of Class VIII Year 2018/2019. The used instrument was the test instrument to measure the critical thinking ability and the learning outcomes of the knowledge aspect, the non-test instrument in the form of questionnaire that was used to measure attitude, while the observation sheet was used to measure the students' skills. The data was analyzed using the simple regression equation. The result of the research showed that there was no influence of the critical thinking ability towards the learning outcomes.
\end{abstract}

(C) IJERE. All rights reserved

Keywords:

Critical thinking ability, learning outcomes.

\section{INTRODUCTION}

Science is a teaching and learning process that studies events and symptoms that occur in the universe that aims to improve the ability of knowledge, skills, and attitudes developed through learning and experimental or investigative experience. Science is a science that studies natural phenomena through a series of processes known as scientific processes that are built on scientific attitudes and the results are realized as scientific products composed of three important components in the form of universally valid concepts, principles and theories (Trianto, 2013: 141).

Thinking is a mental activity experienced by someone when facing with a problem or problem that must be solved according to Sagala (2011). It can be shown to be able to understand the problem that is solved by the problem so that he must do an activity called thinking. According to Ansari (1996), in the teaching and learning process in the classroom, there are many teachers who close the opportunities for criticality of their students by not providing the learning that increases their creativity. Sometimes the students do not understand the purpose of the obtained materials because they only accept the materials provided by the teacher. On the other hand in the learning process, the teacher must convey the purpose of the delivered learning.

SMP Katolik Stella Maris Biudukfoho is located in Biudukfoho village, Rinhat District, Malaka Regency. Schools that are still developing, are located close to the city center and are sufficient in terms of facilities and infrastructure. The abilities of the students were still sufficient for all subjects. On the other hand, working on a science problem was still low. This can be seen from the results of each student's test. The students tended to answer questions without using completion steps so that they found it difficult to answer questions (interviews of the teacher). In this case, the role of a teacher is very important because a teacher is a professional educator who has the main task of educating, teaching, guiding, directing, training, and evaluating the students in early childhood education through formal channels of basic education and secondary education (Law No. 14 of 2005). As a motivator and facilitator, a teacher must be able to teach so that he can optimize the critical thinking ability of the students so that the students can solve the problem correctly and understand the purpose of the problem.

Based on the problems faced by the students in understanding science subjects, the researcher was interested in conducting a research on the influence of the critical thinking ability of the students in class VIII of science subjects at SMP Katolik Stella Maris Biudukfoho. In addition, to maximize the critical thinking ability, the students could understand the concepts that had been taught by the teacher to achieve the

\footnotetext{
${ }^{1}$ Student of Master of Science Education, Sebelas Maret University, Surakarta, yohanatabun96@student.uns.ac.id,orcid.org/0000-0001-7871-4992

${ }^{2}$ Lecturer of Physics Education, Sebelas Maret University, Surakarta, widhasunarno@staff.uns.ac.id,orcid.org/0000-0001-8264-3509

3 Lecturer of Physics Education, Sebelas Maret University, Surakarta, Sukarmin67@staff.uns.ac.id ,orcid.org/0000-0002-3767-0660
} 
objectives of the learning. Thinking can be interpreted as the initial knowledge that can be obtained by connecting between one and another in the form of concepts, ideas, or understanding so that a conclusion is formed. Thinking includes learning activities, thinking people get new discoveries, at least people become aware of the relationship between things (Dalyono, 2007). In connection with the opinion of Plato in Suryabrata (2001: 54), thinking is an ideational activity. Then, Plato also thought that thinking was speaking in the heart.

Critical thinking is an intellectual thinking process in which thinkers deliberately assess the quality of their thinking, thinkers use reflective, independent, clear, and rational thinking. Critical thinking is an important and high level skill to solve complicated and sharp problems that need in-depth analysis (Wardani, et al., 2019). Critical thinking is empowering cognitive skills or strategies in determining goals (Achmad, 2007). The process is passed after setting goals, considering, and referring directly to the target - a form of thinking that needs to be developed in order to solve problems, form conclusions, gather various possibilities, and make decisions when using all of these skills effectively in the right context and type. Therefore, indicators of critical thinking ability can be derived from the critical activities of the students.

According to Ennis (in Maftukhin, 2013: 24), there are five groups of indicators of critical thinking ability, namely as follows: a) Elementary Clarification. Basic clarification is divided into three indicators, namely (1) identifying or formulating questions, (2) analyzing arguments, and (3) asking questions and answering clarification questions and/or challenging questions, b) Giving Reasons for a Decision (The Base for The Decision). This stage is divided into two indicators, namely (1) considering the credibility of a source and (2) observing and considering the results of observations, c) Inference. The concluding stage consists of three indicators (1) making a deduction and considering the results of deduction, (2) making an induction and considering the results of the induction, and (3) making and considering the decision value, d) Further Clarification. This stage is divided into two indicators, namely (1) identifying terms and considering definitions and (2) referring to unspecified assumptions and e) Supposition and Integration. This stage is divided into two indicators (1) consider and think logically about the premise, reasons, assumptions, positions, and other proposals that are not approved by them or that make them feel hesitant without making disagreements or doubts that disturb their mind, and (2) combining other abilities and dispositions in making and maintaining a decision.

Learning outcomes are a number of experiences that the students process that cover cognitive, affective, and psychomotor domains (Rusman, 2013: 130). Learning is not only mastery of subject theory concepts, but also mastery of habits, perceptions, pleasures, interests, social adjustment, types of skills, ideals, desires, and expectations. The learning outcomes of the students are the changes in behavior and as feedbacks in an effort to improve the teaching and learning process. Learning outcomes are the result of an interaction between learning and teaching (Dimyati and Mudjiono, 2006: 3). Based on the opinions above, it can be concluded that the learning outcomes are the changes in the students' behavior through learning activities that are displayed in cognitive knowledge that is appropriate to their teaching goals. Based on the description above, it can be concluded that the learning outcomes of the science students are the abilities that the students have in science subjects derived from experiences and exercises during the teaching and learning process that describe the students' mastery of science subjects which can be seen from the science value and ability to solve science issues.

\section{METHOD}

The method used in this study was a quantitative method. The objective was to find out the influence of the critical thinking ability on the learning outcomes of the students in class VIII of science subjects at SMP Katolik Stella Maris Biudukfoho. The type of this study was a case study aimed to determine the critical thinking ability of the students on the learning outcomes in science subjects. The population used in this study was class VIII at SMP Katolik Stella Maris Bidukfoho, while the samples were class VIII A and B amounting 60 students. 
Tabun,Y.F., Sunarno,W. \& Sukarmin (2019). The effectiveness of critical thinking ability on learning outcomes at SMP Katolik Stella Maris Biudukfoho, Indonesia. International Journal of Educational Research Review,4(4),593-601.

Tabel 1. The Summary of the Characteristics of the Respondents

\begin{tabular}{llll}
\hline \multicolumn{1}{c}{ Variables } & Description & Frequency & Precentage (\%) \\
\hline Gender & Male & 21 & $35 \%$ \\
& Female & 39 & $65 \%$ \\
\hline Semester of study & 2 & 60 & $100 \%$ \\
\hline Age & 13 & 15 & $25 \%$ \\
& 14 & 27 & $45 \%$ \\
& 15 & 18 & $30 \%$ \\
\hline
\end{tabular}

(Mustofa, R. H., et al., 2019)

As shown in Table 1, the first column is the gender of the respondents consisting of 21 male and 39 female. It can be seen that more female respondents were involved in this study with a percentage of $65 \%$, while male respondents were $35 \%$. The second column shows the semester level taken by the respondents when the study was conducted, namely semester 2 . The third column shows the age of the respondents, such as the age of 13 years consisting of 15 students with a percentage of $25 \%$, the age of 14 years as many as 27 students with a percentage of $45 \%$, and the age of 15 years consisting of 18 students with a percentage of $30 \%$.

The data collection instrument contained 10 adaptation questions as follows:

Tabel 2. Questionnaire Development

\begin{tabular}{|c|c|c|c|}
\hline & Variables & Indicators & Adaptation \\
\hline$(\mathrm{X})$ & Critical thinking ability & $\begin{array}{ll}\text { - } & \text { Elementary Clarification } \\
\text { - } & \text { The Basis for the Decision } \\
\text { - Inference } \\
\text { - Advanced Clarification } \\
\text { - Supposition and Integration }\end{array}$ & $\begin{array}{l}\text { Ennis (1996), Maftukhin } \\
\text { (2013) }\end{array}$ \\
\hline$(\mathrm{Y})$ & Science learning outcomes & $\begin{array}{ll}\text { - } & \text { Aspects of Knowledge } \\
\text { - } & \text { Attitude Aspects } \\
\text { - } & \text { Skill Aspects }\end{array}$ & $\begin{array}{l}\text { Rusman (2013), Bloom, B. } \\
\text { (1908), Dimyati and Mudjiono } \\
\text { (2006) }\end{array}$ \\
\hline
\end{tabular}

(Mustofa, R. H., et al., 2019)

The data analysis using a simple regression equation can be written as follows: The reason for using a simple regression equation test was because the researcher wanted to find out the influence between the two variables which was the ability to think critically about the learning outcomes of the students in science subjects.

\section{RESULTS}

The results of data analysis were aided by the SPSS application at the 0.05 significance level. The variables used in this study included the dependent variable $(\mathrm{Y})$ : science learning outcomes (values) and free variable $(\mathrm{X})$ : critical thinking ability. 
Tabun,Y.F., Sunarno,W. \& Sukarmin (2019). The effectiveness of critical thinking ability on learning outcomes at SMP Katolik Stella Maris Biudukfoho, Indonesia. International Journal of Educational Research Review,4(4),593-601.

\subsection{Effectiveness of Critical Thinking Ability on Learning Outcomes in the Aspect of Knowledge}

Table 3. Variables and Methods Entered/Removed Variables ${ }^{b}$

\begin{tabular}{ccc} 
Model & $\begin{array}{c}\text { Entered } \\
\text { Variables } \\
1\end{array} \begin{array}{c}\text { Able } \\
\text { Variables } \\
\text { think_critical a }\end{array}$ & to \\
a. All requested variables entered & Enter \\
b. Dependent Variable: Learning Results & \\
\hline
\end{tabular}

From the SPSS output, Tabel 3 describes the included variables and the used method. In this case, the entered variable is the variable test of the critical thinking ability as the independent variable and the learning outcomes of the aspect of knowledge (value) as the dependent variable and the used method was the entered method.

Table 4. Correlation/Relationship Value (R)

\begin{tabular}{|c|c|c|c|c|}
\hline \multicolumn{5}{|c|}{ Model Summary } \\
\hline \multirow[b]{2}{*}{ Model } & & $\mathrm{R}$ & Adjusted R & $\overline{\text { Std. Error }}$ \\
\hline & $\mathrm{R}$ & Square & Square & of the Estimate \\
\hline 1 & $.190^{a}$ & .36 & .19 & 9,229 \\
\hline
\end{tabular}

From the output of SPSS at Table 4, it explains the value of correlation/relationship (R) which is equal to 0.190 . From the table, it obtains a coefficient of determination (R square) of 0.036 which implies that the influence of independent variables (tests of critical thinking ability) on the dependent variable (the learning outcomes of the aspect of knowledge) is $3.6 \%$.

Table 5. Value F Calculate

ANOVA $^{b}$

\begin{tabular}{|c|c|c|c|c|c|}
\hline Model & Sum of Squares & Df & Mean Square & $\mathrm{F}$ & Sig. \\
\hline 1 Regression & 184,525 & 1 & 184,525 & 2.166 & $.146^{\mathrm{a}}$ \\
\hline Residual & 4940,058 & 58 & 85,173 & & \\
\hline Total & 5124,583 & 59 & & & \\
\hline
\end{tabular}

a. Predictors: (Constant), critical thinking ability

b. Dependent Variable: Learning Results

From the SPSS output, Table 5 explains the value of $f$ count (2.166) with a significance level $(0.146$ $<0.05$ ). The regression model could be used to predict the learning outcome variables. In other words, there was no influence of the critical thinking ability variable $(X)$ on the learning outcomes of the aspect of knowledge $(Y)$. 
Table 6. Constant value Coefficients ${ }^{a}$

\begin{tabular}{lrrrrr}
\multicolumn{7}{c}{$\begin{array}{l}\text { Unstandardized } \\
\text { Coefficients }\end{array}$} & \multicolumn{2}{c}{$\begin{array}{l}\text { Standardized } \\
\text { Coefficients }\end{array}$} & & \\
Model & B & Std. Error & Beta & $\mathrm{t}$ & \multicolumn{1}{c}{ Sig. } \\
1 (Constant) & 42,026 & 17,969 & & 2,339 & .023 \\
Critical-thinking ability & .309 & .210 & .190 & 1,472 & .146 \\
a. Dependent Variable: Learning Results & & & & & \\
\hline
\end{tabular}

Based on the SPSS output at Table 6, it explains that the Constant value (a) is 42,026 , while the value of the critical thinking ability (b/regression coefficient) is 0.309 . So, the regression equation can be written as follows:

$$
\mathrm{Y}=\mathrm{a}+\mathrm{bX} \text { or } 42,026+0.309 \mathrm{X}
$$

The coefficient $b$ is called the regression direction coefficient and states that the average change of variable $Y$ for each change in variable $X$ is equal to one unit. This change is an increase if $b$ is positive and it is a decrease if $b$ is negative. So, the equation can be translated as follows: (1) a constant of 42,026 states that if there is no value of the critical thinking ability, the value of the learning outcomes of the knowledge aspect is 42,026 , (2) $\mathrm{X}$ regression coefficient of 0.309 states that in each addition of 1 value of the critical thinking ability, the value of the students' learning outcomes of the knowledge aspect increases by 0.309 .

Based on the output above, it can be seen that the value of $t$ count is 1.472 with a significance value of $0.146>0.05$. So, $\mathrm{H}_{0}$ was accepted and $\mathrm{H}_{1}$ was rejected. This means that there was no significant influence of the variable of the critical thinking ability $(X)$ towards the variable of the students' learning outcomes of the knowledge aspect $(Y)$.

\subsection{Effectiveness of Critical Thinking Ability on Learning Outcomes in the Aspect of Attitude}

Table 7. Variables and Methods

Entered/Removed Variables ${ }^{b}$

\begin{tabular}{|c|c|c|c|}
\hline Model & $\begin{array}{l}\text { Entered } \\
\text { Variables }\end{array}$ & $\begin{array}{l}\text { Removed } \\
\text { Variables }\end{array}$ & Method \\
\hline 1 & \multicolumn{2}{|l|}{$\begin{array}{l}\text { Ableto } \\
\text { think_critical a }\end{array}$} & . Enter \\
\hline \multicolumn{4}{|c|}{ a. All requested variables entered. } \\
\hline
\end{tabular}

From Table 7 above, it describes the included variables and the used method. In this case, the entered variable was the variable of critical thinking ability as the independent variable and the learning outcomes of the aspect of attitude (value) as the dependent variable and the used method was the entered method.

Table 8. Correlation/Relationship Value (R) Model Summary

\begin{tabular}{ccccc} 
Model & R & R Square & $\begin{array}{l}\text { Adjusted } \\
\text { Square }\end{array}$ & \multicolumn{2}{c}{$\begin{array}{c}\text { R Std. Error of } \\
\text { the Estimate }\end{array}$} \\
1 & $.115^{\mathrm{a}}$ & .13 & -004 & 9,877 \\
\multicolumn{2}{l}{ a. Predictors: (Constant), critical thinking ability } & \\
\hline
\end{tabular}

Table 8 explains the magnitude of the value of correlation/relationship (R) which is equal to 0.115 . From the table, it obtains the coefficient of determination ( $R$ square) of 0.013 , which implies that the 
Tabun,Y.F., Sunarno,W. \& Sukarmin (2019). The effectiveness of critical thinking ability on learning outcomes at SMP Katolik Stella Maris Biudukfoho, Indonesia. International Journal of Educational Research Review,4(4),593-601.

influence of the independent variable (critical thinking ability) on the dependent variable (the learning outcomes of the aspect of attitude) is $1.3 \%$.

Table 9. Value F Calculate ANOVA ${ }^{b}$

\begin{tabular}{lrrrrr} 
& \multicolumn{1}{c}{ Sum of } & \multicolumn{1}{c}{ Mean } \\
Model & Squares & \multicolumn{1}{c}{ df } & Square & \multicolumn{1}{c}{ F } & Sig. \\
1 Regression & 75,634 & 1 & 75,634 & .775 & $.382^{a}$ \\
$\quad$ Residual & 5658,016 & 58 & 97,552 & & \\
$\quad$ Total & 5733,650 & 59 & & &
\end{tabular}

a. Predictors: (Constant), critical thinking ability

b. Dependent Variable: Learning Results

Table 9 explains the value of $\mathrm{f}$ arithmetic $(0.775)$ with a significance level $(0.382>0.05)$. The regression model could be used to predict the learning outcomes of the aspect of attitude (value). In other words, there was no influence of the critical thinking ability variable $(X)$ on the learning outcomes of the attitude variable (Y).

Table 10. Constant value Coefficients ${ }^{a}$

\begin{tabular}{llrrrr}
\multicolumn{7}{c}{$\begin{array}{l}\text { Unstandardized } \\
\text { Coefficients }\end{array}$} & \multicolumn{2}{c}{ Standardized } \\
Coefficients & & \\
Model & B & Std. Error & Beta & $\mathrm{t}$ & Sig. \\
1 (Constant) & 66,254 & 1930 & & 3,445 & .001 \\
Critical-thinking ability & .198 & .225 & .115 & .881 & .382 \\
a. Dependent Variable: Learning Results & & & & \\
\hline
\end{tabular}

Based on the SPSS output at Table 10, it explains that the Constant value (a) is 66,254 , while the value of the critical thinking ability (b/regression coefficient) is 0.198 . So, the regression equation can be written as follows:

$$
\mathrm{Y}=\mathrm{a}+\mathrm{bX} \text { or } 66,254+0.198 X
$$

The coefficient $b$ is called the regression direction coefficient and states that the average change of variable $\mathrm{Y}$ for each change in variable $\mathrm{X}$ is equal to one unit. This change is an increase if $\mathrm{b}$ is positive and it is a decrease if $b$ is negative. So, the equation can be translated as follows: (1) a constant of 66,254 states that if there is no value of the critical thinking ability, the value of the learning outcomes of the attitude aspect is 66,254, (2) X regression coefficient of 0.198 states that in each addition of 1 value of the critical thinking ability, the value of the students' learning outcomes of the attitude aspect increases by 0.198 .

Based on the output above, it can be seen that the value of $t$ count is 0.881 with a significance value of $0.382>0.05$. So, $\mathrm{H}_{0}$ was accepted and $\mathrm{H}_{1}$ was rejected. This means that there was no significant influence of the variable of the critical thinking ability $(X)$ towards the variable of the students' learning outcomes of the attitude aspect $(\mathrm{Y})$. 
Tabun,Y.F., Sunarno,W. \& Sukarmin (2019). The effectiveness of critical thinking ability on learning outcomes at SMP Katolik Stella Maris Biudukfoho, Indonesia. International Journal of Educational Research Review,4(4),593-601.

3.3 Effectiveness of Critical Thinking Ability on Learning Outcomes in the Aspect of Learning Skills

Table 11. Variables and methods Entered/Removed Variables ${ }^{b}$

\begin{tabular}{rlrl} 
& Entered & Removed & \\
Model & Variables & Variables & Method \\
1 & Able to & Enter \\
think_critical a & \\
a. All requested variables entered. \\
b. Dependent Variable: Learning Results \\
\hline
\end{tabular}

Table 11 above describes the included variables and the used method. In this case, the entered variable was the variable of critical thinking ability as the independent variable and the learning outcomes of the aspect of skills (value) as the dependent variable and the used method was the entered method.

Table 12. Correlation/Relationship Value (R) Model Summary

\begin{tabular}{ccccc} 
Model & $\mathrm{R}$ & R Square & $\begin{array}{l}\text { Adjusted } \\
\text { Square }\end{array}$ & \multicolumn{2}{c}{$\begin{array}{c}\text { R Std. Error of } \\
\text { the Estimate }\end{array}$} \\
1 & $.167 \mathrm{a}$ & .28 & .11 & 6,478 \\
\multicolumn{2}{l}{ a. Predictors: (Constant), critical thinking ability } \\
\hline
\end{tabular}

Table 12 explains the magnitude of the value of the correlation/relationship (R) which is equal to 0.167. From the table, it obtains the coefficient of determination ( $R$ square) of 0.028 , which implies that the influence of the independent variable (critical thinking ability) on the dependent variable (the aspect of learning skills) is $2.8 \%$.

Table 13. Value F Calculate ANOVA ${ }^{b}$

\begin{tabular}{lccccc}
\hline Model & Sum of Squares & df & Mean Square & F & Sig. \\
1 Regression & 69,684 & 1 & 69,684 & 1,660 & $.203^{\mathrm{a}}$ \\
Residual & 2434,049 & 58 & 41,966 & & \\
Total & 2503,733 & 59 & & & \\
a. Predictors: (Constant), critical thinking ability & & & \\
b. Dependent Variable: Learning Results & & &
\end{tabular}

Table 13 describes the value of $f$ arithmetic $(1.660)$ with a significance level $(0.203>0.05)$. The regression model could be used to predict the learning outcomes of the aspect of learning skills (value). In other words, there was no influence of the critical thinking ability variable $(X)$ on the variable of the aspect of learning skills $(\mathrm{Y})$. 
Tabun,Y.F., Sunarno,W. \& Sukarmin (2019). The effectiveness of critical thinking ability on learning outcomes at SMP Katolik Stella Maris Biudukfoho, Indonesia. International Journal of Educational Research Review,4(4),593-601.

Table 14. Constant value Coefficients ${ }^{a}$

\begin{tabular}{llrrrr}
\hline \multicolumn{7}{c}{ Unstandardized } & \multicolumn{2}{c}{ Standardized } \\
Coefficients & Coefficients & & \\
Model & B & Std. Error & Beta & $\mathrm{t}$ & Sig. \\
1 (Constant) & 64,049 & 12,613 & & 5,078 & .000 \\
$\quad$ Critical-thinking ability & .190 & .147 & .167 & 1,289 & .203 \\
a. Dependent Variable: Learning Results & & & & \\
\hline
\end{tabular}

Based on the SPSS output at Table 14, it explains that the Constant value (a) is 64,049, while the value of the critical thinking ability (b/regression coefficient) is 0.190 . So, the regression equation can be written as follows:

$$
\mathrm{Y}=\mathrm{a}+\mathrm{bX} \text { or } 64,049+0.190 \mathrm{X}
$$

The coefficient $b$ is called the regression direction coefficient and states that the average change of variable $Y$ for each change in variable $X$ is equal to one unit. This change is an increase if $b$ is positive and it is a decrease if $\mathrm{b}$ is negative. So, the equation can be translated as follows: (1) a constant of 64,049 states that if there is no value of the critical thinking ability, the value of the learning outcomes of the skill aspect is 64,049 , (2) X regression coefficient of 0.190 states that in each addition of 1 value of the critical thinking ability, the value of the students' learning outcomes of the skill aspect increases by 0.190 .

Based on the output above, it can be seen that the value of $t$ count is 1.289 with a significance value of $0.203>0.05$. So, $\mathrm{H}_{0}$ was accepted and $\mathrm{H}_{1}$ was rejected. This means that there was no significant influence of the variable of the critical thinking ability $(X)$ towards the variable of the students' learning outcomes of the skill aspect $(Y)$.

\section{CONCLUSION}

Based on the results of the research and analysis, conclusions are obtained as follows:

1. The Influence of the Critical Thinking Ability towards the Learning Outcomes of the Knowledge Aspect The result of the research of the learning outcomes of the knowledge aspect was obtained that the value of $t$ count is 1.472 and the significance value is $0.146>0.05$. This means that $\mathrm{H}_{0}$ was accepted and $\mathrm{H}_{1}$ was rejected. Based on the result of the data analysis, the price of $R$ is 0.190 according to Table 2 which is included in the low criteria, while the contribution of the critical thinking towards the science learning outcomes of the knowledge aspect is 3.6\% and the remaining of 96.4 is determined by other factors. The simple regression equation is that the Constant of 42,026 states that if the value of the critical thinking is 0 , the ability to solve the science problems is 42,026 . The regression coefficient of 0.309 states that each addition of $1 \%$ value to the students' critical thinking would increase the science learning outcomes of the knowledge aspect by 0.309 . Thus, the critical thinking ability did not influence the students' learning outcomes of science of the knowledge aspect.

2. The Influence of the Critical Thinking Ability towards the Learning Outcomes of the Attitude Aspect The result of the research of the learning outcomes of the attitude aspect was obtained that the value of $t$ count is 0.881 and the significance value is $0.382>0.05$. This means that $\mathrm{H}_{0}$ was accepted and $\mathrm{H}_{1}$ was rejected. Based on the result of the data analysis, the price of $R$ is 0.115 according to Table 2 which is included in the low criteria, while the contribution of the critical thinking towards the science learning outcomes of the knowledge aspect is $1.3 \%$ and the remaining of 98.7 is determined by other factors. The simple regression equation is that the Constant of 66,254 states that if the value of the critical thinking is 0 , the ability to solve the science problems is 66,254 . The regression coefficient of 0.198 states that each addition of $1 \%$ value to the students' critical thinking would increase the science learning outcomes of the attitude aspect by 0.198 . Thus, the critical thinking ability did not influence the students' learning outcomes of science of the attitude aspect.

3. The Influence of the Critical Thinking Ability towards the Learning Outcomes of the Skill Aspect

The result of the research of the learning outcomes of the skill aspect was obtained that the value of $t$ count is 1.289 and the significance value is $0.203>0,05$. This means that $\mathrm{H}_{0}$ was accepted and $\mathrm{H}_{1}$ was 
Tabun,Y.F., Sunarno,W. \& Sukarmin (2019). The effectiveness of critical thinking ability on learning outcomes at SMP Katolik Stella Maris Biudukfoho, Indonesia. International Journal of Educational Research Review,4(4),593-601.

rejected. Based on the result of the data analysis, the price of $R$ is 0.167 according to Table 2 which is included in the low criteria, while the contribution of the critical thinking towards the science learning outcomes of the skill aspect is $2.8 \%$ and the remaining of 97.2 is determined by other factors. The simple regression equation is that the Constant of 64,049 states that if the value of the critical thinking is 0 , the ability to solve the science problems is 64,049 . The regression coefficient of 0.190 states that each addition of $1 \%$ value to the students' critical thinking would increase the science learning outcomes of the skill aspect by 0.190 . Thus, the critical thinking ability did not influence the students' learning outcomes of science of the skill aspect. This study was still not perfect. Therefore, it is suggested to other researchers to conduct more in-depth researches for the same problem so that more comprehensive results are obtained.

\section{REFERENCES}

Achmad, A. (2007). Memahami Berpikir Kritis. [online]. Tersedia: http://re-searchengines.com/1007arief3.html.

Ansari, K. (1996). Pengembangan Kemampuan Berpikir Kritis Menyongsong Era Teknologi Pada Abad Ke-21. Pikiran Rakyat 267.

Bloom, B. (1908). Psikologi pendidikan. Jakarta.

Dalyono, M. (2007). Psikologi Pendidikan. Jakarta: Rineka Cipta.

Dimyati \& Mudjiono (2006). Belajar dan pembelajaran. Jakarta: Rineka Cipta

Ennis, R.H. (1996). Crytical thinking. New Jersey: Prentice Hall.

Komariyah, Siti.,dkk. (2018). Pengaruh Kemampuan Berpikir Kritis Terhadap Hasil Belajar Matematika: Jurnal Penelitian Pendidikan dan Pengajaran Matematika, 4(2), 55-60 .

Mustofa, R. H., Riani, A. L. \& Wardani, D. K. (2019). The impact of policy: How scientific publication policy and socio-economics status affect motivation and types of publication among graduate students. International Journal of Educational Research Review, 4(2), 121-132.

Rusman, (2013). Model - model Pembelajaran mengembangkan profesionalisme guru. Jakarta: Raja Grafindo Persada.

Sagala, S. (2011). Konsep dan makna pembelajaran. Bandung: Alfabeta.

Sumadi, S. (2001). Psikologi Kepribadian. Cetakan ke 4. Jakarta: Raja Grafindo Pustaka.

Wardani, D. K., Martono, T., Pratomo, L. C., Rusydi, D. S. \& Kusuma, D. H. (2019). Online learning in higher education to encourage critical thinking skills in the 21st century. International Journal of Educational Research Review, 4(2), 146-153. 